Bayero Journal of Pure and Applied Sciences, 5(2): $136-142$

Received: September 2012

Accepted: December 2012

ISSN $2006-6996$

\title{
EFFECT OF LOW GLYCAEMIC INDEX MEALS ON INSULIN SECRETION IN DIABETIC AND APPARENTLY HEALTHY SUBJECTS
}

\author{
Alegbejo, J.0. \\ Paediatrics Department, Ahmadu Bello University Teaching Hospital, Shika, Zaria, Nigeria \\ janetalegbe@yahoo.com
}

\begin{abstract}
One of the potential effects of low glycaemic index (low-GI) diets is to reduce insulin secretion in patients with type 2 diabetes. The effects of low GI meals (Acha, Rice and Eba) on serum insulin were elicited in diabetic type 2 subjects. Ten diabetic and 6 healthy individuals participated in the study. Fasting blood samples were taken and after consumption of the reference (glucose) and test meals (Acha, Rice and Eba) every 30 minutes until two and half hours post - consumption. Serum blood glucose level was determined using glucose oxidase method while insulin level was determined using Enzyme-Linked Immunosorbent Assay (ELISA). Insulin responses to the various meals in the diabetic subjects were initially lower $(p<0.05)$ compared to those in the control and also the insulinogenic indices were significantly lower in the diabetics than the control $(p<0.05)$. In the type 2 diabetic patients however, despite higher increments of serum glucose, only modest changes of plasma insulin occurred initially but later the insulin responses continued to increase up to two and half hour but the hyperglycaemia continued leading to a much lower ratio. This is to show that there is a state of impaired pancreatic beta-cell function since insulinogenic index is a measure of $\beta$-cell secretary function and also the insulin produced is not effective. Therefore, diabetic individuals consuming low glycaemic meals may not be producing effective insulin to clear the hyperglycaemia being produced by these meals.
\end{abstract}

Keywords: type 2 diabetics, low glycaemic index, insulin, insulinogenic indices

\section{INTRODUCTION}

Dietary intake can influence insulin levels, especially among individuals who are insulin resistant due to factor such as obesity. Dietary glycaemic load (GL), which is a quantitative measure of the glycaemic effect of food, has been associated with triglycerides and high-density lipoprotein levels (Brand-Miller, 1994: Liu et al., 2001and Ford and Liu, 2001), as well as the risk of diabetes (Salmeron et al., 1997a; Salmeron et al., 1997b) and heart disease (Liu et al., 2000). Postprandial insulin responses are not always proportional to blood glucose concentrations or to a meal's carbohydrate content (Holt et al., 1997). It has been shown that when low-glycaemic carbohydrates are incorporated into an energy-deficient diet, there is a greater fall in insulin resistance than can be accounted for by weight loss alone (Slabber et al., 1994).

One of the potential effects of low-GI diets is to reduce insulin secretion in patients with type 2 diabetes and to reduce daily insulin requirements in patients with type 1 diabetes. Wolever et al. (1994) observed a $30 \%$ reduction in urinary C-peptide levels in subjects with type 2 diabetes on a low-GI diet, indicating reduced endogenous insulin demand. The wider implementation of a low-GI diet will depend on the continuing identification of low-GI foods.

Diets with a low-GI or glycaemic load elicit lower postprandial insulin responses and produce better clinical outcomes compared with diets with higher GI or GL (Mckeown et al., 2004; Barclay et al., 2008; Reynolds et al., 2008). Carbohydrate counting and knowledge of the GI of foods provide the most accurate prediction of likely insulin response (Kaufman et al., 1999; Gilbertson et al., 2001). A physiologic basis for classifying all foods according to their postprandial insulin response is of both theoretical and practical significance. In individuals at risk of developing type 2 diabetes, diets that provoke excessive insulin secretion may increase oxidative stress and accelerate the course of $\beta$ - cell failure (Porte, 2001).

Although carbohydrate is the primary stimulus for insulin secretion, it is not the only one. Protein-rich foods also elicit a significant insulin response and, when combined with carbohydrate, act synergistically to raise insulin concentrations and reduce glycemia (Gannon et al., 1988). Similarly, addition of fat to a carbohydrate rich meal reduces postprandial glycemia but not the insulin response (Gannon et al., 1993; Collier et al., 1988). Several insulinotropic factors are known to potentiate the stimulatory effect of glucose and mediate postprandial insulin secretion. These factors include specific amino acids and fatty acids and gastrointestinal hormones such as gastric inhibitory polypeptide, glucagon-like peptide 1, glucagon, and cholecystokinin (Collier et al., 1988; Frid et al., 2005).

Evidence has accumulated during the last decade on the significant roles of both decreased insulin sensitivity and $\beta$-cell dysfunction in the pathogenesis of type 2 diabetes mellitus (DM).

Both insulin secretion and insulin sensitivity are genetically and environmentally controlled and the impairment of both has individually or together been associated with increasing risk of developing type 2 DM (Pimenta et al., 1995; Polonsky et al., 1996; Weyer et al., 1999). 
It has been reported that during each stage of the development of type $2 \mathrm{DM}$, decreased insulin sensitivity and insulin secretory dysfunction are independent predictors of worsening glucose tolerance (Weyer et al., 2001). Indeed, fasting hyperinsulinaemia, known to reflect decreased insulin sensitivity, together with decreased insulin secretion are the strongest independent predictors of type 2 DM (Haffner et al., 1997).

Therefore, the classification of the relative insulinaemic effects of different foods is of both theoretical and practical significance. Postprandial blood glucose responses have been the focus of much research because of their importance for glycaemic control in patients with diabetes. In a bid to expand the existing information on glycaemic index and insulin responses of the local meals in our nation, this study was conducted to systematically compare postprandial insulin responses to known low glycaemic index meal in diabetic and non - diabetic subjects, so that dietary variety and palatability are not compromised.

\section{MATERIALS AND METHODS}

Ten diabetic subjects and six healthy subjects participated in each meal on two different mornings after 10-12 hours fasting. Informed consent for inclusion into the study was obtained from the subjects who fulfilled the inclusion criteria. The nature of the study was explained to the subjects in the language spoken by him or her. The subjects were instructed not to change their physical activity patterns during the period of the study because that might influence peripheral sensitivity to insulin and thus might have an effect on the glycaemic and insulinaemic indices. The protocol and procedure was approved by the scientific and ethical committee of Ahmadu Bello University Teaching Hospital Shika, Zaria.

\section{Meals}

The test meals acha (Digitaria exelis Stapf) rice (Oryza sativa L) and eba (Manihot esculanta Cranz) were prepared according to the usual Nigerian methods. Food Macronutrients were calculated using food composition table by Enwere, (1998). Analytical methods

The fasting blood sample was collected into plain tubes and was left to clot for about 15 minutes which was promptly centrifuged at 1,500 revolutions per minute (rpm) using a centrifuge (Hettich, Universal) for 15 minutes. The serum was analyzed for glucose on the same day of collection and the remaining serum was stored in plain bottles. Sera samples were aliquots into $2 \mathrm{ml}$ tubes which were kept on ice, then stored at $-20^{\circ} \mathrm{C}$ until further analysis for insulin assay. The serum glucose concentration were determined using the enzymatic colorimetric method of Randox (Cat. no. GL 2614 Randox Laboratories Ltd., Antrim,UK) while plasma insulin concentrations were measured by a commercially available enzyme linked Immunosorbent Assay (ELISA) human insulin kit manufactured by DEMEDITEC Diagnostics GmbH D.24145 Kiel Germany (2006).
Following the fasting blood samples, the glucose (standard) solution or meals was given and completely eaten within 15 minutes by each subject. The time of complete consumption was recorded as zero minutes. Blood samples were taken at times of $30,60,90,120$ and 150 minutes after consumption of the meals. Analysis for glucose and insulin were carried out as for the fasting.

\section{Glycaemic index (GI)}

The GI from the two and half hour glucose area of acha, rice and eba meals were determined by using standard protocol (FAO/WHO, 1998) with anhydrous glucose as the reference food (glycaemic index = 100).

Incremental areas under the concentration-time curve (IAUC) were calculated by the trapezoidal method for serum glucose (Wolever et al., 1991). The IAUC obtained for glucose was considered to correspond to a glycaemic index (GI) of 100,

The glycaemic index was expressed as a percent of the response to the same amount of carbohydrate from a standard food taken by the same subject. GI values were classified as low $(<55)$ (Brand- Miller et al., 2003), and the GI of meals in both subjects were calculated based on their incremental area under the curve (IAUC) expressed relative to the reference IAUC of the glucose. The GI for each food was taken as the average of all 10 individuals' values for diabetic subjects and average of all 6 individuals' value for control subjects.

\section{Insulinogenic index}

The incremental insulin area under the curve (AUC) over 150 min for each meal was calculated according to the trapezoidal rule with the fasting concentration as the baseline (Wolever et al., 1991). Area below the fasting concentration was ignored. For each subject, an individual relative insulin response was calculated by dividing the insulin AUC value for the test meal by his or her average insulin AUC value for glucose (tested twice). Insulinogenic index was calculated as the ratio incremental value of serum insulin level divided by the relative net increase of serum glucose level.

\section{Statistical Analysis}

Statistical analyses were carried out using SPSS 17.0 Software (Statistical Package for Social Sciences, Inc, Chicago, IL, USA). Data was presented as mean plus or minus standard deviation of the mean for GI, serum insulin and insulinogenic indices. Paired student $t$ test was used to compare the effects of glucose versus meal in diabetics, glucose versus meal in healthy subjects. Unpaired student t test was used to find the differences between the healthy and diabetic subjects. The significance level was set at $\mathrm{P}<0.05$.

\section{RESULTS}

The glycaemic index and glycaemic loads in both diabetic and control groups are shown in Table 1 . The mean insulin response to acha was significantly higher in the control at 30 minutes than the type 2 diabetic subjects $\mathrm{p}<0.05$ (Table 2). 
Meanwhile the mean insulinogenic indices to acha were significantly lower at $30-120$ minutes for the diabetic subjects than the control $\mathrm{p}<0.05$ (Table 3 ). The overall insulinogenic index to acha was significantly lower in diabetic subjects than the control $p<0.05$. The fasting serum insulin level was significantly lower in the diabetic subjects than control subjects at $(p<0.05)$ in the group that consumed eba. Also after ingestion of eba the mean serum insulin level was significantly lower at 30 minutes in the diabetic subjects than control subjects, but at 120 and 150 minutes it became significantly higher in the diabetic subjects than control subjects $(p<0.05)$
(Table 2). The insulinogenic indices of eba meal were significantly lower in type - 2 diabetic subjects at 30 60 minutes than control subjects $(P<0.05)$ (Table 3$)$. The mean serum insulin levels in diabetic and control subjects after consumption of rice are shown in Table 2. After the consumption of rice the control subjects had significantly higher insulin responses at 30 minutes, but by 150 minutes the diabetic subjects had significantly higher insulin production when compared to control subjects $(p<0.05)$. The insulinogenic indices were significantly lower in the diabetics from $30-120$ minutes than control subjects $(p \leq 0.05)$ (Table 3 ).

Table 1: Glycaemic indices and glycaemic loads of meals fed to diabetic and control subjects

\begin{tabular}{l|l|l|l|l}
\hline & \multicolumn{2}{|c|}{$\begin{array}{c}\text { Glycaemic Index } \\
\text { N = 10 }\end{array}$} & \multicolumn{2}{c}{$\begin{array}{c}\text { Glycaemic Load } \\
\text { N = 6 }\end{array}$} \\
\hline Meals & $\begin{array}{l}\text { Diabetes } \\
\text { subjects }\end{array}$ & Control subjects & $\begin{array}{l}\text { Diabetes } \\
\text { subjects }\end{array}$ & Control subjects \\
\hline Acha & $49.28 \pm 11.52$ & $35.38 \pm 22.32$ & 24.5 & 17.5 \\
Rice & $52.14 \pm 8.11$ & $40.24 \pm 16.43$ & 26.0 & 20.0 \\
Eba & $52.51 \pm 6.45$ & $49.87 \pm 10.38$ & 26.5 & 25 \\
\hline
\end{tabular}

Values are presented as mean \pm standard deviation. \# = values are calculated from the GI. $\mathrm{N}=$ number of subjects

Table 2: Mean serum insulin level of Type 2 diabetics and control subjects fed with Acha, Rice, and Eba meals

\begin{tabular}{|c|c|c|c|c|c|c|}
\hline \multirow[b]{2}{*}{$\begin{array}{l}\text { Time } \\
\text { (Min) }\end{array}$} & \multicolumn{3}{|c|}{$\begin{array}{c}\text { Diabetic subjects } \\
\mathbf{N}-\mathbf{1 0} \\
\end{array}$} & \multicolumn{3}{|c|}{$\begin{array}{c}\text { Control subjects } \\
N=6\end{array}$} \\
\hline & $\begin{array}{l}\text { Acha } \\
\text { meal }\end{array}$ & $\begin{array}{l}\text { Rice } \\
\text { meal }\end{array}$ & $\begin{array}{l}\text { Eba } \\
\text { meal }\end{array}$ & $\begin{array}{l}\text { Acha } \\
\text { meal }\end{array}$ & $\begin{array}{l}\text { Rice } \\
\text { meal }\end{array}$ & $\begin{array}{l}\text { Eba } \\
\text { meal }\end{array}$ \\
\hline 0 & $4.03 \pm 0.09$ & $6.41 \pm 0.92^{b}$ & $7.51 \pm 0.07^{5}$ & $3.67 \pm 1.50$ & $1.39 \pm 0.37^{b}$ & $2.93 \pm 1.83^{\mathrm{S}}$ \\
\hline 30 & $7.91 \pm 1.55^{\mathrm{a}}$ & $9.11 \pm 1.15^{c}$ & $9.90 \pm 0.95^{d}$ & $24.27 \pm 9.91^{\mathrm{a}}$ & $38.25 \pm 15.17^{c}$ & $43.64 \pm 10.67^{d}$ \\
\hline 60 & $11.39 \pm 2.83$ & $10.12 \pm 1.28$ & $15.95 \pm 2.25$ & $19.02 \pm 7.77$ & $18.25 \pm 4.86$ & $27.81 \pm 6.98$ \\
\hline 90 & $16.23 \pm 3.80$ & $13.30 \pm 3.18$ & $20.72 \pm 3.28$ & $15.78 \pm 6.44$ & $13.64 \pm 4.28$ & $16.93 \pm 3.91$ \\
\hline 120 & $10.27 \pm 1.87$ & $17.12 \pm 3.30$ & $26.38 \pm 4.27^{f}$ & $12.07 \pm 4.93$ & $12.42 \pm 4.15$ & $10.46 \pm 3.34^{f}$ \\
\hline 150 & $17.62 \pm 5.17$ & $20.07 \pm 5.12^{\mathrm{e}}$ & $29.05 \pm 5.55^{\mathrm{g}}$ & $7.51 \pm 3.07$ & $4.77 \pm 2.72^{\mathrm{e}}$ & $5.34 \pm 2.90^{g}$ \\
\hline
\end{tabular}

Values in $\mu \mathrm{IU} / \mathrm{ML}$ are means \pm SD. Values in the same row with same superscripts are significantly different $(p<0.5) . N=$ number of subjects

Table 3: Insulinogenic indices of Type 2 diabetics and control subjects fed with acha, rice, and eba meals

\begin{tabular}{rcccccc}
\hline & \multicolumn{3}{c}{ Diabetic subjects } & \multicolumn{3}{c}{ Control subjects } \\
\hline $\begin{array}{r}\text { Time } \\
\text { (Min) }\end{array}$ & $\begin{array}{c}\text { Acha } \\
\text { meal }\end{array}$ & $\begin{array}{l}\text { Rice } \\
\text { meal }\end{array}$ & $\begin{array}{l}\text { Eba } \\
\text { meal }\end{array}$ & $\begin{array}{c}\text { Acha } \\
\text { meal }\end{array}$ & $\begin{array}{l}\text { Rice } \\
\text { meal }\end{array}$ & $\begin{array}{l}\text { Eba } \\
\text { meal }\end{array}$ \\
\hline 30 & $0.84 \pm 0.32^{\mathrm{a}}$ & $0.53 \pm 0.10^{\mathrm{b}}$ & $0.57 \pm 0.24^{\mathrm{c}}$ & $15.54 \pm 5.33^{\mathrm{a}}$ & $20.76 \pm 9.68^{\mathrm{b}}$ & $25.03 \pm 10.90^{\mathrm{c}}$ \\
60 & $1.18 \pm 0.43^{\mathrm{d}}$ & $0.38 \pm 0.08^{\mathrm{e}}$ & $1.41 \pm 0.40^{\mathrm{f}}$ & $6.48 \pm 1.93^{\mathrm{d}}$ & $7.93 \pm 3.89^{\mathrm{e}}$ & $9.88 \pm 3.16^{\mathrm{f}}$ \\
90 & $1.80 \pm 0.49^{\mathrm{g}}$ & $0.67 \pm 0.26^{\mathrm{h}}$ & $2.49 \pm 0.99$ & $8.38 \pm 3.82^{\mathrm{g}}$ & $3.48 \pm 1.41^{\mathrm{h}}$ & $6.19 \pm 3.09$ \\
120 & $1.06 \pm 0.43^{\mathrm{k}}$ & $1.43 \pm 0.38^{\mathrm{l}}$ & $2.26 \pm 0.72$ & $6.03 \pm 2.16^{\mathrm{k}}$ & $4.84 \pm 1.59^{1}$ & $4.02 \pm 1.76$ \\
150 & $1.63 \pm 0.66$ & $3.02 \pm 1.11$ & $5.13 \pm 1.77$ & $2.50 \pm 1.48$ & $1.99 \pm 1.27$ & $6.16 \pm 2.84$ \\
\hline
\end{tabular}

Values in the same row with same superscripts are significantly different $(p<0.5)$. Values are presented as mean \pm standard deviation. $\mathrm{N}=$ number of subjects

\section{DISCUSSION}

These three meals used in this work were reported as low glycaemic index meals by Alegbejo et al. (2009a, $2009 \mathrm{~b}$ and 2011) and also all the meals had high glycaemic load. It has been shown that when lowglycaemic carbohydrates are incorporated into an energy-deficient diet, there is a greater fall in insulin resistance than can be accounted for by weight loss alone (Slabber et al., 1994). Also, diets with a lower glycaemic index or glycaemic load produce better clinical outcomes and elicit lower postprandial insulin responses when compared with diets with higher GI or GL (Barclay et al., 2008; Mckeown et al., 2004; Reynolds et al., 2008) but it was not the case in this study because the diabetic subjects responded initially to the meals by producing lower quantity of insulin and gradually increased in the production then became higher consistently compared to the control subjects. 
Prolonged or high degrees of postprandial insulinemia are thought to contribute to the development of insulin resistance and associated diseases (Gannon et al., 1993; Collier et al., 1988 Frid et al., 2005). Hyperinsulinemia, a marker of insulin resistance (Ronnemaa et al., 1991), has been demonstrated to be a strong predictor for type 2 diabetes (Lillioja et al., 1987; Eriksson et al., 1989; Martin et al., 1992; Henriksen et al., 1994; Haffner et al., 1995; Mykkänen et al., 1993). Type 2 diabetic subjects are usually characterized by peripheral insulin resistance, $\beta$-cell failure, and increased hepatic glucose production (1988). The physiologic importance of postprandial hyperinsulinemia is unknown, particularly if the corresponding level of glycemia is low, as in this case. Hyperinsulinemia may be pathogenic when associated with dyslipidemia, hypertension, impaired fibrinolysis and other features of the metabolic syndrome (Stout, 1996).

Low GIs is characterized by slower rates of digestion and absorption in the small intestine, nutrient receptors in the gastrointestinal tract are stimulated for a longer period of time, resulting in prolonged feedback (through signals such as cholecystokinin and glucagon-like peptide-1) to the satiety center in the brain (Lavin et al., 1998). Reducing the rate of digestion of carbohydrate spreads the absorption of carbohydrate along a longer portion of the small intestine (Balfour and McTavish, 1993; Jenkins and Wolever 1981), and tends to increase the amount of carbohydrate which escapes digestion in the small intestine (Jenkins et al., 1981). For example, the amount of carbohydrate from lentils entering the colon is 2.5 times as great as carbohydrate from bread. Increasing the delivery of starch to the colon has many implications which include those on the health of the colon itself and on systemic metabolism. It is believed that starch entering the colon is completely and rapidly fermented, mostly in the caecum (Cummings and Macfarlane, 1991). The fermentation of starch produces relatively more butyrate than the fermentation of dietary fibre (Cummings and Macfarlane, 1991) and resistant starch produces somewhat different fermentation products than readily digested starch (Nordgaard et al., 1995).

The insulin response varied between the meals in both the diabetic and the control subjects but the insulin production remained high in the diabetic subjects even at two and half hour, yet there was hyperglycaemia. Insulinotropic factors, such as protein- and fat-rich foods, may induce substantial insulin secretion despite producing relatively small blood glucose responses (Krezowski et al., 1986; Peter and Davidson, 1993). In this study the meals contained all the macronutrients and this may also contribute to more insulin production. Although carbohydrate is the primary stimulus for insulin secretion, it is not the only one. Protein-rich foods also elicit a significant insulin response and, when combined with carbohydrate, act synergistically to raise insulin concentrations and reduce glycaemia (Gannon et al., 1988), but the glycaemia was not reduced in the diabetic subjects. In a study comparing glucose to insulin response to foods, the authors reported that although the two scores were highly correlated, the glycaemic response accounted for only $23 \%$ of the variability in insulinaemia (Holt et al., 1997). It has long been recognized that the chronic hyperglycemia associated with type 2 diabetes (glucose toxicity) leads to impairment in insulin secretion and a possible defect in glycogen synthesis but it was not the same in this study (Rosetti et al., 1990).

In this study, control subjects had consistently higher mean insulinogenic indices than their type 2 diabetic subjects. Insulinogenic indices represent dynamic interactions between changing levels of plasma insulin and changing levels of plasma glucose. The control subjects expectedly had significantly and consistently higher indices than their type 2 diabetic counterparts. Nondiabetic pancreases self-regulate the amount of insulin secreted, acting in response to changes in blood glucose concentration that result from the ingestion of food. In people with diabetes, however, bolus and basal glucose levels are increased; In addition, a study of type 2 diabetic Japanese patients recently showed that decreased insulin secretion had a more pronounced impact on glucose tolerance than insulin sensitivity (Fukushima et al., 2004). Both glucose toxicity and lipotoxicity have been reported to contribute to $\beta$ - cell dysfunction. Furthermore, decreased $\beta$ - cell function may exist already at normal fasting blood glucose levels (Godsland et al., 2004).

This study showed that both $\beta$ - cell dysfunction and insulin resistance may be responsible for the hyperglycaemia associated with type 2 diabetes mellitus. The clients that were enrolled prior to treatment randomization, into the United Kingdom Prospective Diabetes Study, underwent 3 months of non-pharmacological treatment with emphasis on lifestyle changes. Therefore, implementation of a healthier life style with an increase in physical activity and a reduction of body weight, based on the regulation of calories and fat intake, are the basis for the prevention of type 2 diabetes (Tuomilehto et al., 2001; Knowler et al., 2002; Laaksonen et al., 2005) and the same principles apply to basic treatment of type 2 diabetes (Pastors et al., 2002; Sigal et al., 2004). Low-GI foods may benefit weight control in 2 ways: 1) by promoting satiety and 2) by promoting fat oxidation at the expense of carbohydrate oxidation. These 2 qualities of low-GI foods stem from the slower rates at which they are digested and absorbed and the corresponding effects on postprandial glycaemia and hyperinsulinemia. Even when appearance and nutrient content are matched, low-GI foods typically induce higher satiety than do their high-GI counterparts and are followed by less energy intake at subsequent meals (Ludwig, 2000). 


\section{REFERENCES}

Alegbejo, J. O., Ameh, D. A., Ogala W. M. and Ibrahim, S. (2009a). Glycaemic responses and Glycaemic load of parboiled long grain rice with vegetable/carrot sauce in healthy and type-2 diabetic subjects. Biological and Environmental Sciences Journal for the Tropics 6 (3):38-41.

Alegbejo, J. O., Ameh, D. A., Ogala, W. N. and Ibrahim, S. (2009b). Glycaemic response to cassava meal (EBA) with okra soup in healthy and type II diabetic subjects. Biotropic Research International Journal 1(1):95-99.

Alegbejo, J. O., Ameh, D. A., Ogala W. M. and Ibrahim, S. (2011). Glycaemic index and load of Acha (Fornio) in healthy and diabetic subjects. Journal of Pure and Applied Microbiology, 5(1):117-122.

Balfour, J.A. and McTavish, D. (1993) Acarbose: an update of its pharmacology and therapeutic use in diabetes mellitus. Drugs, 46:1025-1054.

Barclay, A. W., Petocz, P., McMillan-Price, J., Flood UM, Prvam T, Mitchell $P$, and Brand-Miller JC (2008). Glycaemic index, glycaemic load, and chronic disease risk a meta-analysis of observational studies. American Journal of Clinical Nutrition, 87: 627-37.

Brand- Miller J.C. (1994). Importance of glycaemic index in diabetes. American Journal of Clinical Nutrition, 59: 747 - 52S.

Brand-Miller, J., T.M.S. Wolever, K. Foster-Powell and S. Colagiuri, (2003). The New Glucose Revolution: The Authoritative Guide to the Glycaemic Index Marlowe and Company, New York.

Collier G.R, Greenberg G.R,Wolever T.M, and Jenkins D.J. (1988). The acute effect of fat on insulin secretion. Journal of Clinical Endocrinology Metabolism, 66:323-6.

Cummings, J.H. and Macfarlane, G.T. (1991). The control and consequences of bacterial fermentation in the human colon. Journal of Applied Bacteriology, 70:443-59.

DeFronzo RA: Lilly Lecture in 1987. (1988): the triumvirate: -cell, muscle, liver: collusion responsible for type II diabetes. Diabetes, 37:667-687.

Demeditec. (2006). Insulin enzyme immunoassay for the quantitative determination of insulin in serum and plasma. User's manual January, Diagnostics GmbH D.24145 Kiel Germany.

Enwere, N.J. (1998). Food of plant Origin. Afro-Orbis publication. University of Nigeria, Nsukka. Nigeria pp 1-301.

Eriksson, J., Franssila-Kallunki, A., Ekstrand, A., Saloranta, C., Widen, E., Schalin, C, and Groop, L. (1989). Early metabolic defects in persons at increased risk for non-insulin-dependent diabetes mellitus. New England Journal of Medicine, 321:337-343.

FAO/WHO, (1998). Dietary Carbohydrates in Human Nutrition. Plotting of joined FAO/WHO expert
Rome consultation 14-18 April 1997. Food and nutrition paper $\mathrm{nE66}$

Ford, E.S and Liu, S. (2001). Glycaemic index and serum high-density lipoprotein cholesterol concentration among US adults. Archive of Internal Medicine, 161: $572-6$.

Frid, A.H, Nilsson, M, Holst, J J, and Bjorck, I.M.E (2005). Effect of whey on blood glucose and insulin responses to composite breakfast and lunch meals in type 2 diabetic subjects. American Journal of Clinical Nutritrion, 82: 6975.

Fukushima, M, Suzuki, H, and Seino Y. (2004). Insulin secretion capacity in the development from normal glucose tolerance to type 2 diabetes. Diabetes Research for Clinical Practice, 66(Suppl.):S37-S43.

Gannon, M.C, Nuttall, F.Q, Neil, B.J, and Westphal SA (1988). The insulin and glucose responses to meals of glucose plus various proteins in type II diabetic subjects. Metabolism, 37: 1081-8.

Gannon, M.C, Nuttall, F.Q, Westpha,I S.A, and Seaquist ER (1993). The effect of fat and carbohydrate on plasma glucose, insulin, Cpeptide, and triglycerides in normal male subjects. Journal of American Coll Nutrition, 12:36-41.

Gilbertson, H.R, Brand-Miller, J.C, Thorburn, A.W, Evans, S, Chondros, $\mathrm{P}$, and Werther, G.A (2001). The effect of flexible low glycaemic index dietary advice versus measured carbohydrate exchange diets on glycaemic control in children with type 1 diabetes. Diabetes Care, 24:1137-43.

Godsland, I.F, Jeffs, J.A, and Johnston D.G. (2004). Loss of beta-cell function as fasting glucose increases in the non-diabetic range. Diabetologia, 47: 1157-1166.

Haffner, S.M, Miettinen, H, Gaskill, S.P, and Stern, M.P. (1995): Decreased insulin secretion and increased insulin resistance are independently related to the 7-year risk of NIDDM in MexicanAmericans. Diabetes, 44:1386-1391.

Haffner, S.M, Miettinen, H, and Stern MP (1997). Are risk factors for conversion to NIDDM similar in high and low risk populations? Diabetologia, 40: 62-66.

Henriksen, J.E, Alford, F, Handberg, A, Vaag, A, Ward, G.M, and Kalfas, A. (1994): Increased glucose effectiveness in normo-glycaemic but insulin resistant relatives of patients with noninsulindependent diabetes mellitus. Journal of Clinical Investigation, 94:1196-1204.

Holt, S.H, Mille,r J.C and Petocz, P. (1997). An insulin index of foods: the insulin demand generated by $1000-\mathrm{kJ}$ portions of common foods. American Journal of Clinical Nutritrion, 66: 1264 $-76$.

Jenkins, D.J.A. and Wolever, T.M.S. (1981). Slow release carbohydrate and the treatment of diabetes. The Proceedings of the Nutrition Society, 40:227-235. 
Jenkins, D.J.A., Taylor, R.H., Goff, D.V., Fielden, H., Misiewicz, J.J., Sarson, D.L., Bloom, S.R. and Alberti, K.G.M.M. (1981). Scope and specificity of acarbose in slowing carbohydrate absorption in man. Diabetes, 30: 951-54.

Kaufman, F.R, Halvorson, M and Carpenter, S. (1999). Use of a plastic insulin dosage guide to correct blood glucose levels out of the target range and for carbohydrate counting in subjects with type 1 diabetes. Diabetes Care, 22: 1252-7.

Knowler, W.C., Barrett-Connor, E., Fowler, S. E., Hamman, R. F., Lachin, J.M., Walker, E. A, and Nathan, D. M. (2002). Reduction in the incidence of type 2 diabetes with lifestyle intervention or metformin. New England Journal of Medicine, 346: 393-403.

Krezowski, P.A, Nuttall, F.Q, Gannon, M.C and Bartosh, N.H. (1986). The effect of protein ingestion on the metabolic response to oral glucose in normal individuals. American Journal of Clinical Nutritrion, 44: 847 - 56.

Laaksonen, D E, Lindström, ], Lakka, T.A, Eriksson, J.G, Niskanen, L, Wikström, K, Aunola, S, Keinänen-Kiukaanniemi, $\mathrm{S}$, Laakso, $\mathrm{M}$, Valle, T.T, Ilanne-Parikka, $\mathrm{P}$, Louheranta, A, Hämäläinen, $\mathrm{H}$, Rastas, $M$, Salminen, $\mathrm{V}$, Cepaitis, $\mathrm{Z}$, Hakumäki, $\mathrm{M}$, Kaikkonen, $\mathrm{H}$, Härkönen, $\mathrm{P}$, Sundvall, J, Tuomilehto, J and Uusitupa, M. (2005). Physical activity in the prevention of type 2 diabetes: the Finnish diabetes prevention study. Diabetes 2005; 54: 158-165.

Lavin, J.H,Wittert, G.A, Andrews, J, Yeap, B, Wishart, J.M, Morris, H.A, Morley, J.E, Horowitz, $M$ and Read, H.M. (1998). Interaction of insulin, glucagonlike peptide 1, gastric inhibitory polypeptide, and appetite in response to intraduodenal carbohydrate. American Journal of Clinical Nutritrion, 1998; 68: 591-8.

Lillioja, S, Mott, D.M, Zawadzki, J.K, Young, A.A, Abbot,t W.G.H, Knowler, W.C, Bennett, P.H, Moll, $\mathrm{P}$ and Bogardus, C. (1987). In vivo insulin action is familial characteristic in nondiabetic Pima Indians. Diabetes $36: 1329-1335$.

Liu, S., Willett, W., Stampfer M.J, Hu, F., Franz, M. Sampson, L. and Heinekens, C. (2000). A prospective study of dietary glycaemic load, carbohydrate intake, and risk of coronary heart disease in US Women. American Journal of Clinical Nutrition, 71:1455-1461.

Liu, S., Manson, J. E., Stampfer, M. J., Holmes, M. D., Hu, F. B., and Hankinson, S. E., (2001) Dietary glycaemic load assessed by food frequency questionnaire in relation to plasma highdensity-lipoprotein cholesterol and fasting plasma triacylglycerols in postmenopausal women. American Journal of Clinical Nutrition, 73(3): 560-566.

Ludwig, D.S. (2000). Dietary glycaemic index and obesity. Journal of Nutrittion, 130(suppl):280S3S.

Martin, B.C, Warram, J.H, Krolewski, A.S, Bergman, R.N, Soeldner, J.S and Kahn, R.C. (1992). Role of glucose and insulin resistance in development of type 2 diabetes mellitus: result of a 25-year follow-up study. Lancet, 340: 925929.

McKeown, N.M, Meigs, J.B, Liu, S, Saltzman, E, Wilson, P.W.F and Jacques, P.F. (2004). Carbohydrate nutrition, insulin resistance, and the prevalence of the metabolic syndrome in the Framingham Offspring Cohort. Diabetes Care, 27: 538-46.

Mykkänen, L, Kuusisto, J, Pyörälä, K and Laakso, M. (1993): Cardiovascular disease risk factors as predictors of type 2 (non-insulin-dependent) diabetes mellitus in elderly subjects. Diabetologia, 36:553-559.

Nordgaard, I., Mortensen, P.B. and Langkilde, A.M. (1995). Small intestinal malabsorption and colonic fermentation of resistant starch and resistant peptides to short-chain fatty acids. Nutrition, 11: 129-37.

Pastors, J.G, Warshaw, H, Daly, H, Franz, M and Kulkarni, K. (2002). The evidence for the effectiveness of medical nutrition therapy in diabetes management. Diabetes Care, 25:608613.

Peters, A.L and Davidson, M.B. (1993). Protein and fat effects on glucose responses and insulin requirements in subjects with insulin-dependent diabetes mellitus. American Journal of Clinical Nutritrion, 58: $555-60$.

Pimenta, W, Korytkowski, M, Mitrakou, A, Jenssen, T, Yki-Jarvinen, $\mathrm{H}$, Evron, W, Dailey, $\mathrm{G}$ and Gerich, J. (1995). Pancreatic beta-cell dysfunction as the primary genetic lesion in NIDDM. JAMA, 273:1855-1861.

Polonsky, K.S, Sturis, J and Bel,I G.I. (1996). Seminars in medicine of the Beth Israel Hospital, Boston. Non-insulin-dependent diabetes mellitus-a genetically programmed failure of the beta cell to compensate for insulin resistance. New England Journal Medicine, 21: 777-783.

Porte, D. J. (2001). Clinical importance of insulin secretion and its interaction with insulin resistance in the treatment of type 2 diabetes mellitus and its complications. Diabetes Metabolic Research Review, 17: 181-8.

Reynolds, R.C, Stockmann, K.S, Atkinson, F.S, Denyer, G.S and Brand-Miller, J.C. (2008). Effect of the glycaemic index of carbohydrates on day-long $(10 \mathrm{~h})$ profiles of plasma glucose, insulin, cholecystokinin and ghrelin. Europian Journal of Clinical Nutrition [serial online] 10.1038/ejcn.2008.52.

Rönnemaa, T, Laakso, M, Pyörälä, K, Kallio, V and Puukka, P. (1991). High fasting plasma insulin is an indicator of coronary heart disease in noninsulin dependent diabetic patients and non-diabetic subjects. Arteriosclerosis Thrombosis 15:80-90.

Rosetti, L., Glaccari, A. and Defronzo, R.A. (1990). Glucose toxicity. Diabetes Care, 13: 610-630

Salmeron, J., Aseherio, A., Rimm, E.B., Colditz, G.A., Spiegelman, D., Jenkins, D.J., Stampter, M.J., Wing, A.I. and Willet, W.C. (1997a). Dietary 
fibre, glycaemic load/index and risk of NIDDM Salmeron, J, Manson, J.E, Stampfer, M.J, Colditz, G.A, Wing, A.L and Willett, W.C. (1997b). Dietary fiber, glycaemic load, and risk of noninsulin-dependent diabetes mellitus in women. JAMA 277: $472-7$.

Sigal, R.J, Kenny, G.P, Wasserman, D.H and Castaneda-Sceppa, C. (2004). Physical activity/exercise and type 2 diabetes. Diabetes Care, 27(10):2518-2539.

Slabber, M., Barnard, H.C., Kuyl, J.M., Dannhauser, A. and Schall, R. (1994). Effects of a lowinsulin-response, energy restricted diet in weight loss and serum insulin concentrations in hyper-insulinaemic obese females. American Journal of Clinical Nutrition, 60: 48-53.

Stout, R. (1996) Hyperinsulinemia and atherosclerosis. Diabetes 45. (suppl. 3): S45-S46.

Tuomilehto, J, Lindstrom, J, Eriksson, J.G, Valle, T.T, Hamalainen, $\mathrm{H}$, Ilanne-Parikka, $\mathrm{P}$, KeinanenKiukaanniemi, S, Laakso, M, Louheranta, A, Rastas, M, Salminen, $V$ and Uusitupa, $M$, for the Finnish Diabetes Prevention Study Group (2001). Prevention of type 2 diabetes mellitus by changes in lifestyle among subjects with impaired glucose tolerance. New England Journal Medicine, 344:13431350.

Weyer, C, Bogardus, C, Mott, D.M and Pratley, R.E. (1999). The natural history of insulin secretory dysfunction and insulin resistance in the pathogenesis of type 2 diabetes mellitus. Journal of Clinical Investigation, 104:787-794.

Weyer, C, Tataranni, P.A, Bogardus, C and Pratley, R.E. (2001). Insulin resistance and insulin secretory dysfunction are independent predictors of worsening of glucose tolerance during each stage of type 2 diabetes development. Diabetes Care, 24:89-94. in men. Diabetes Care, 20(4): 545-550.

Wolever, T, Nguyen, P, Chiasson, J, Hunt, J, Josse, R, Palmason, C, Rodger, N.W, Ross, S.A, Ryan, E.A, and Tan, M.H. (1994). Determinants of diet glycaemic index calculated retrospectively from diet records of 342 individuals with non-insulin-dependent diabetes mellitus. American Journal of Clinical Nutritrion, 59:1265-1269.

Wolever, T.M.S., Jenkins, D.J.A., Jenkins, A.L. and Josse, R.G. (1991). The glycaemic index, methodology and clinical implications. American Journal of Clinical Nutrition, 54: 846-854. 